\title{
Erythropoietin protection effects against ischemia-reperfusion injuries during coronary artery bypass graft surgery: a randomized, double blinded, placebo control study
}

\author{
SH Ziabakhsh Tabary*, F Mokhtari-Esbui \\ From 23rd World Congress of the World Society of Cardio-Thoracic Surgeons \\ Split, Croatia. 12-15 September 2013
}

\section{Background}

Although the rapid reperfusion by coronary artery bypass graft (CABG) surgery has significant success and it can cause decrease in mortality and morbidity rate, but this reperfusion paradoxically can cause ionic and metabolic damage that lead to myocardial damage and myocytes death. We examined whether perioperative exogenous erythropoietin (EPO) can reduce myocardial damage by reducing troponin I and creatine kinase (CKMB) level.

\section{Methods}

43 patients randomly divided into two groups. Patients in erythropoietin group were treated by common medical therapies and CABG plus $700 \mathrm{IU} / \mathrm{kg}$ erythropoietin (PD Poietin, puyeshdaroo, Iran), intravenously infusion, exactly 5 min after termination of cross clamp: at the start of reperfusion and patients in control group were treated by common medical therapies and CABG surgery plus $10 \mathrm{cc}$ normal saline as placebo. CKMB and Troponin I, were measured before and 8 hours after surgery. Echocardiography was performed 4 days after surgery in all patients.

\section{Results}

No differences were detected between EPO and control group in change of troponin from before to after surgery $(1.41 \pm 2.09$ vs. $1.79 \pm 1.42$ with $\mathrm{P}=0.49)$. There were no significant differences between change of CKMB from before to after surgery in EPO and control group (20.59 \pm 17.51 vs. $11.57 \pm 14.46$ with $\mathrm{P}=0.07)$. Also Wall

\footnotetext{
* Correspondence: shervin_zia@yahoo.com

Mazandaran University of Medical Sciences, Mazandaran Heart Center, Sari,
} Iran

(c) 2013 Ziabakhsh Tabary and Mokhtari-Esbui; licensee BioMed Central Ltd. This is an Open Access article distributed under the terms
Cite this article as: Ziabakhsh Tabary and Mokhtari-Esbui: Erythropoietin protection effects against ischemia-reperfusion injuries during coronary artery bypass graft surgery: a randomized, double blinded, placebo control study. Journal of Cardiothoracic Surgery 2013 8(Suppl 1):0209.

Submit your next manuscript to BioMed Central and take full advantage of:

- Convenient online submission

- Thorough peer review

- No space constraints or color figure charges

- Immediate publication on acceptance

- Inclusion in PubMed, CAS, Scopus and Google Scholar

- Research which is freely available for redistribution

Submit your manuscript at 